\title{
Multimodal Evoked Potentials of Kennedy's Disease
}

\author{
Tsu-Hsien Lai, Bing-Wen Soong, Jen-Tse Chen, Yen-Yu Chen, Kuan-Lin Lai, \\ Zin-An Wu, Kwong-Kum Liao
}

\begin{abstract}
Background: Kennedy's disease (KD) is an X-linked recessive polyglutamine disease. Traditionally, it is a lower motor neuron syndrome with additional features such as gynecomastia and tremor. Sensory symptoms are minimal if ever present. We used multimodal evoked potential (EPs) tests to study the distribution of the involvement of the disease. Methods: Visual, brainstem auditory, somatosensory and motor EPs were studied in six KD patients. All of them had typical presentations and had been proved genetically. Results: Abnormal findings were noted as follows: prolonged peak latencies of visual EPs, increased hearing threshold level, inconsistent brainstem auditory EPs, decreased amplitudes of cortical potentials of somatosensory EPs, and increased motor threshold to transcranial magnetic stimulation. Conclusions: Our multimodal EP studies showed that KD involved multiple levels of the nervous system. It implies the widespread effects of the mutant androgen receptors.
\end{abstract}

RÉSUMÉ: Potentiels évoqués multimodaux dans la maladie de Kennedy. Contexte : La maladie de Kennedy (MK) est une maladie récessive à polyglutamines, liée au chromosome X. Il s'agit traditionnellement d'un syndrome du neurone moteur périphérique accompagné d'autres manifestations comme de la gynécomastie et du tremblement. Si des symptômes sensitifs sont présents, ils sont minimes. Nous avons utilisé les potentiels évoqués (PÉs) multimodaux pour étudier la distribution de l'atteinte dans cette maladie. Méthodes : Nous avons étudié les PÉs visuels, les PÉs auditifs du tronc cérébral, les PÉs somesthésiques et les PÉs moteurs chez six patients atteints de MK. Chez tous, le tableau était typique et la maladie avait été confirmée par un test génétique. Résultats : Les anomalies suivantes ont été constatées : des latences prolongées du pic des PÉs visuels, un seuil auditif plus élevé, des PÉs auditifs du tronc cérébral discordants, une amplitude diminuée des potentiels corticaux des PÉs somesthésiques et un seuil moteur plus élevé à la stimulation magnétique transcrânienne. Conclusions : Nos études des PÉs multimodaux démontre que plusieurs niveaux du système nerveux sont atteints dans la MK, ce qui témoigne des effets diffus des récepteurs androgéniques mutants.

Can. J. Neurol. Sci. 2007; 34: 328-332

Kennedy's disease (KD), also known as X-linked bulbospinal muscular atrophy, is characterized by slowly progressive proximal and bulbar weakness, muscular atrophy, fasciculation with predominance of facial muscles, and additional symptoms including gynecomastia and postural tremor. It is caused by an expansion of a polymorphic tandem cytosine-adenine-guanine (CAG) repeat on Xq12 in the first exon of the androgen receptor gene encoding a polyglutamine stretch. ${ }^{1,2}$ Its clinical symptoms overlap with other neuromuscular disorders, for example, amyotrophic lateral sclerosis or spinal muscular atrophies, and clinical signs are nonspecific in early stages of the disease. Thus, clinical diagnosis of KD may still be difficult. ${ }^{3}$

The impact of KD on the central nervous system (CNS) has gained much attention in the last few years. ${ }^{3-7}$ Multimodal evoked potentials (EPs) can be used to evaluate the CNS involvement and also provide information about CNS structures, such as the spinal cord and the optic nerves, which are not as well visualized by magnetic resonance imaging (MRI), but are of great importance in causing disability in patients with neurological disorders, such as mitochondrial disease. Though it is generally agreed that genetic testing is very important in the diagnosis of KD, EPs might still help in revealing subtle

From the Department of Neurology (THL, BWS, JTC, KLL, ZAW, KKL), Taipei Veterans General Hospital; Department of Neurology (THL, BWS, JTC, KLL, ZAW, KKL), National Yang Ming University School of Medicine; Department of Neurology (THL), Cathay General Hospital, Taipei, Taiwan; Department of Internal Medicine (JTC), Yuanshan Veterans Hospital, Yilan; Department of Neurology (YYC), Changhua Christian Hospital, Changhua, Taiwan.

ReCEIVED JANUARY 2, 2007. ACCEPTED IN FinAL FORM ApRIL 23, 2007 Reprint requests to:Kwong-Kum Liao, Department of Neurology, Taipei Veterans General Hospital; 201, Section 2, Shih-Pai Road, Taipei, Taiwan 11217, R.O.C. 
neurological dysfunction. Here, we used multimodal EPs to investigate systemically the central sensory and motor pathway function of KD patients.

\section{Methods}

\section{Subjects}

We included six KD patients, two from the same family (patients 2 and 3). The demographics and clinical findings are listed in Table 1. Neurological examination showed motor weakness of each subject and sensory deficits of tactile with glove-and-stocking patterns in three subjects. None of them complained of hearing or visual problems. All the KD patients had increased values of serum creatinine kinase (KD 248-1654 U/L; control 27-168 U/L) and normal values of serum testosterone (KD 4.58-9.37 NG/ML; control 2.36-9.96 NG/ML). They all fit the diagnostic criteria of KD and were diagnosed by genetic testing. The control included ten healthy men matched with age and height. They were studied after informed consents were given. Besides multimodal EP studies, the protocol included standard nerve conduction studies (NCS) and needle electromyography.

Table 1: Demography of patients with Kennedy's disease

\begin{tabular}{|c|c|c|c|c|c|c|}
\hline Patients & 1 & 2 & 3 & 4 & 5 & 6 \\
\hline Age/Sex & $36 \hat{\jmath}$ & $47 \hat{\jmath}$ & $44 \hat{\jmath}$ & $51 \hat{\jmath}$ & $41 \hat{\circ}$ & $71 \hat{\jmath}$ \\
\hline Height (cm) & 169 & 172 & 163 & 163 & 172 & 165 \\
\hline CAG No. & 47 & 48 & 48 & 50 & 53 & 46 \\
\hline Age onset & 30 & 30 & 32 & 37 & 30 & 29 \\
\hline Slurred speech & - & - & - & ++ & - & + \\
\hline Dysphagia & - & + & - & + & - & + \\
\hline Weakness (MRC) & + & + & + & + & ++ & + \\
\hline Fatigue & + & + & + & + & - & + \\
\hline \multicolumn{7}{|l|}{ Fasciculation } \\
\hline Limbs & + & + & - & + & - & + \\
\hline Face & - & + & + & + & + & + \\
\hline Muscle wasting & - & + & - & + & + & + \\
\hline Cramp & ++ & + & + & - & - & - \\
\hline Tremor & + & ++ & ++ & ++ & - & + \\
\hline Gait disorder & - & + & + & + & ++ & + \\
\hline Climbing difficulty & + & + & - & + & ++ & + \\
\hline \multicolumn{7}{|l|}{ Sensory } \\
\hline Numbness & + & - & - & - & - & + \\
\hline Signs & - & + & - & + & - & + \\
\hline Gynecomastia & + & ++ & - & ++ & - & ++ \\
\hline Infertility & + & + & - & - & $\mathrm{s}$ & - \\
\hline Dysuria & - & + & - & - & - & + \\
\hline Diabetes & - & - & - & - & - & + \\
\hline Creatinine kinase & $\uparrow$ & $\uparrow$ & $\uparrow$ & $\uparrow$ & $\uparrow$ & $\uparrow$ \\
\hline Cholesterol & $\mathrm{N}$ & $\uparrow$ & $\mathrm{N}$ & $\mathrm{N}$ & $\mathrm{N}$ & $\mathrm{N}$ \\
\hline ALT & $\mathrm{N}$ & $\uparrow$ & $\uparrow$ & $\mathrm{N}$ & $\mathrm{N}$ & $\mathrm{N}$ \\
\hline Testosterone & $\mathrm{N}$ & $\mathrm{N}$ & $\mathrm{N}$ & $\mathrm{N}$ & $\mathrm{N}$ & $\mathrm{N}$ \\
\hline Motor NCS & $A$ & $A$ & $A$ & $A$ & $A$ & $A$ \\
\hline Sensory NCS & $A$ & $A$ & $A$ & $A$ & A & A \\
\hline EMG & $A$ & $A$ & A & A & A & A \\
\hline
\end{tabular}

CAG: cytosine-adenine-guanine; NCS: nerve conduction study; EMG: electromyography; ++: the initial symptom at onset; + : yes; -: no; s: single; N: within normal limits; A: abnormal

\section{EP studies}

The parameters of EPs were all based upon the guidelines of the International Federation of Clinical Neurophysiology. ${ }^{8-11}$ Pattern visual EPs (VEPs) were obtained to specifically assess the function of optic nerve pathways. Brainstem auditory EPs (BAEPs) were done by $10 \mathrm{~Hz}$ click and were averaged for total 1024 stimuli, focusing on the interpeak latencies of I-V, I-III and III-V. BAEPs were done with binaural stimulators. When click stimuli were applied at one side, white noise masking was employed at the intensity of $40 \mathrm{~dB}$ at another side. Somatosensory evoked potentials (SEPs) were obtained from the upper and lower limbs by electrical stimulation delivered to the median nerve at the wrist and the posterior tibial nerve at the ankle. Responses were recorded from the ipsilateral Erb's point (N9), above the 5th cervical spine (N13) and the contralateral scalp (N20) with reference to Fz for median nerve stimulation; and the 1st lumbar spine -contralateral iliac crest (N22), the 5th cervical spine (P30), and the contralateral scalp (P37) for posterior tibial nerve stimulation. Five hundred responses were averaged for each trial of median nerve stimulation and 1000 responses for tibial nerve stimulation.

Transcranial magnetic stimulation (TMS) with recording on the abductor pollicis brevis of the upper limb was performed with a magnetic stimulator (MagStim 200, Magstim Company, UK) to measure the latency of motor evoked potential (MEP). Motor threshold (MT) was usually estimated at complete rest and was defined as a reliable MEP response with a minimal 50$100 \mu \mathrm{V}$ in five of ten consecutive trials. ${ }^{11}$ When there were active muscle activities in the background, the MT was defined as a minimal response size around $200-300 \mu \mathrm{V}$. The motor central conduction time (CCT) was calculated by subtracting the peripheral motor conducting time from the total latency of the $\mathrm{MEP}$, i.e. motor CCT $(\mathrm{ms})=$ cortical MEP latency - $(\mathrm{F}$ wave latency + distal latency of compound motor action potentials $1) / 2$.

\section{Statistical analysis}

The Wilcoxon Rank Sum test was used to analyze the difference between the KD and control groups. All data were considered significant when the $p$ value was $<0.05$.

\section{RESUlts \\ Routine electrophysiological studies}

The data of electrophysiological studies were summarized in Table 2. Sensory NCS showed decreased sensory nerve action potentials. Motor NCS showed decreased compound muscle motor action potentials but normal conduction time in the forearm or leg segments in the nerves sampled. Needle electromyography revealed denervation in the muscles sampled.

\section{Sensory EPs}

VEPS

Our data (mean \pm standard deviation; SD) showed that our KD patients had significant delayed $\mathrm{P} 100$ in the study of pattern VEPs (KD $113.6 \pm 11.4 \mathrm{~ms}$; control $98.4 \pm 4.9 \mathrm{~ms} ; p<0.0001)$. 
Table 2: Evoked potentials of Kennedy's disease

\begin{tabular}{|c|c|c|c|c|c|c|c|}
\hline Patient & $\frac{\text { VEP }}{\mathrm{P} 100(\mathrm{~ms})}$ & $\mathrm{HL}(\mathrm{dB}) /$ & orm & P37 (ms & $\frac{P}{37-N 45 \mu V)}$ & $\overline{\mathrm{MT}}(\%$ & $\frac{\mathrm{MEP}}{/ \mathrm{CCT}(\mathrm{ms})}$ \\
\hline 1. $L$ & $134^{\neq}$ & 85 & DR & 38.3 & 0.9 & $70^{*}$ & 6.6 \\
\hline $\mathrm{R}$ & $139^{¥}$ & 85 & DR & 36.7 & $0.4^{\#}$ & $70^{¥}$ & 6.8 \\
\hline 2. L & 105 & 100 & DR & 40.4 & 0.8 & 65 & 6.9 \\
\hline $\mathrm{R}$ & 104 & 100 & DR & 39.6 & 0.7 & 60 & 6.7 \\
\hline 3. L & 110 & 85 & DR & 35.1 & 0.8 & 60 & 7.0 \\
\hline $\mathrm{R}$ & 113 & 90 & DR & 35.4 & 0.8 & 65 & 6.7 \\
\hline 4. L & 110 & 90 & DR & 37.7 & 2.0 & 45 & 6.5 \\
\hline $\mathrm{R}$ & $115^{*}$ & 85 & DR & 37.4 & 1.8 & 50 & 6.3 \\
\hline 5. L & 107 & 75 & DR & 36.6 & 0.9 & 55 & 6.8 \\
\hline $\mathrm{R}$ & 104 & 80 & DR & 37.4 & 0.8 & 50 & 7.0 \\
\hline 6. L & $114^{¥}$ & 110 & DR & $46.4^{¥}$ & $0.5^{*}$ & 60 & 7.1 \\
\hline R & 109 & 110 & DR & $47.2^{¥}$ & $0.4^{¥}$ & 60 & 7.0 \\
\hline Mean & $113.6(11.4)$ & $3(11.3)^{*}$ & & $39.9(3.9)$ & $0.9(0.5)^{*}$ & $59.2(7.9)^{*}$ & $6.8(0.2)$ \\
\hline Contro & 98.4 (4.9) & $70(0)$ & & $38.0(2.0)$ & $1.9(0.4)$ & $45.2(7.0)$ & $6.9(0.4)$ \\
\hline
\end{tabular}

BAEP: brainstem auditory evoked potentials; CCT: central motor conduction time; HL (dB): hearing level (decibels); DR: difficult to reproduce; MEP: motor evoked potentials to transcranial magnetic stimulation; MT: motor threshold; SEP: somatosensory evoked potentials; VEP: pattern visual evoked potentials; (): standard deviation; $¥:>3$ standard deviation; * $: p$ value $<0.05$.

\section{BAEPS}

The stimuli, i.e. the hearing threshold level (HL), was at 70 $\mathrm{dB}$ HL for each control subject but increased in KD patients (KD $91.3 \pm 11.3 \mathrm{~dB} \mathrm{HL}$, range: $75-110 \mathrm{~dB} \mathrm{HL})$. Inconsistent waveforms were noted in each KD subject. Therefore, it was difficult to measure the responses after superimposition.

\section{SEPS}

Abnormal SEPs were noted during stimuli at the tibial nerve but not at median nerve. The chief findings were decreased amplitudes of the cortical potentials (KD $0.9 \pm 0.5 \mu \mathrm{V}$; control $1.9 \pm 0.4 \mu \mathrm{V} ; p=0.0002)$.

\section{TMS}

Increased motor threshold was noted in our KD patients (TMS intensity, KD $59.2 \pm 7.9 \%$; control $45.4 \pm 7.2 \%$; $p<0.05$ ). The central motor conduction time was not different between KD and control groups (KD $6.8 \pm 0.2 \mathrm{~ms}$; control $6.9 \pm 0.4 \mathrm{~ms} ; p>$ $0.05)$.

\section{Discussion}

Androgen modulates primary sensory signals via the androgen receptors. ${ }^{12}$ Androgen receptors are widespread in the brain. Using immunohistochemical technique, diffuse nuclear accumulation of mutant androgen receptors has been proved to be far more frequent and extensive in the brain of the $\mathrm{KD}$ patients than thus far believed. ${ }^{13}$ The mutant androgen receptors are distributed not only in the neural tissues but also in the nonneural tissues. The neural tissues included cerebrum, superior colliculus, pons, medulla, cerebellum, spinal cord, dorsal root ganglia, and the sympathetic ganglia; and the non-neural tissues included liver, kidney, pancreas, testis, prostate gland, scrotal skin, and skin.

The VEPs represent a mass response of cortical and possible subcortical visual areas. ${ }^{8}$ VEPs are employed routinely in the assessment of the functional integrity of the visual pathways, i.e. the optic nerve or optic pathways. However, the identity of the cortical generators of pattern VEPs is neither known nor agreed upon. ${ }^{8}$ Androgen receptors exist in the optic nerve head ${ }^{14}$ and the primary visual cortex. ${ }^{15}$ Although eyes and optic nerve were not selected for analysis in the study of Adachi et al, ${ }^{13}$ we inferred that delayed P100 latencies in our KD patients were also due to the accumulation of mutant androgen receptors in the eyes or optic related pathways.

Abnormal BAEPs were noted in our patients despite the fact that none of them complained of hearing loss. Brainstem auditory evoked potential (BAEP) is a simple method to screen hearing function and its related brainstem function. Abnormal BAEPs had been reported in patients with $\mathrm{KD}^{7}$ and spinal muscular atrophy. ${ }^{16}$ In KD patients, the main findings were increased thresholds, delayed wave I latencies and inconsistent waveforms. ${ }^{7}$ Tone audiometry further proved that these KD patients had mild hearing loss at the higher frequency. ${ }^{7}$ In the animal studies, androgen receptor mRNA-containing cells were found in the cochlear nuclei, the lateral lemniscus, and the 
medial geniculate nuclei. ${ }^{17}$ Mutant androgen receptors had been proved in the human pontine nuclei of KD patients. ${ }^{13}$ Hence, in $\mathrm{KD}$ patients, inconsistent BAEP waveforms are probably due to dysfunction of cochlear nuclei or the 8th cranial nerve.

Somatosensory evoked potentials are well known as a method to assess the function of the dorsal column and its related supraspinal pathway. Abnormal SEPs were reported not only in our patients but also in the other series. ${ }^{3,4,6,7,18}$ It is consistent with the pathological studies of KD patients in whom there is loss of myelinated fibers in the fasciculus gracilis and depletion of neurons in the ventral horn throughout the same spinal segments. ${ }^{19}$ It is inferred that the lesion of primary sensory neurons may produce retrograde degeneration of dorsal column. ${ }^{4}$

So far, there were only six TMS studies of KD patients. In 1992, TMS was first applied in 12 KD patients and showed that they all had normal central motor conduction time. ${ }^{6}$ Similar normal results were reported in another four cases later. ${ }^{7,18,20}$ However, Sperfeld et $\mathrm{al}^{3}$ had done TMS in $18 \mathrm{KD}$ patients with different results. Six of them had prolonged onset latencies to the target muscle of abductor pollicis brevis. In these six patients, four of them had prolonged central motor conduction time. Although most pathological studies of KD patients did not find any abnormal findings of the motor cortex or the corticospinal tracts, ${ }^{19,21,22}$ changes of corticospinal tract were reported in two KD patients by Shaw et $\mathrm{al}^{23}$ in 1998 . This could be the reason why some of $\mathrm{KD}$ patients had prolonged central motor conduction time. ${ }^{3,24}$ Although increased MT was the only finding in our series, Pachatz et $\mathrm{al}^{24}$ found that all the parameters of MEP could be altered in KD patients, such as decreased MEP amplitudes, prolonged central motor conduction time, decreased cortical silent period, reduced intracortical inhibition during interstimuli interval of 1-6 ms. Using proton magnetic resonance spectroscopy (MRS), reduced metabolic activities were note in the motor regions and indicated neuronal dysfunction and gliosis in the area. ${ }^{25}$ It is inferred that the gene effect of the trinucleotide repeat mutation in $\mathrm{KD}$ makes the brain susceptible to degeneration and subsequent development of reactive gliosis, even though there are no pathological structural findings. ${ }^{25}$ The correlations were not significant between functional findings (TMS and MRS) and clinical parameters (age at onset, disease duration, or CAG-repeat length). ${ }^{3,25}$

Based upon the current concept, the main pathological findings of $\mathrm{KD}$ were at the spinal cord and brainstem. ${ }^{21}$ However, a few reports showed that KD might also involve cerebral hemispheres. In the case of Shaw et al, ${ }^{23}$ neuronal depletion and gliosis in the hippocampus and subcortical gliosis in the prefrontal region were noted in a $\mathrm{KD}$ patient with cognitive change. Immunostaining for macrophage markers showed evidence for subtle corticospinal tract pathology in two KD patients. ${ }^{23}$ Further evidence is provided by case report of two KD patients, one with dementia and frontal lobe atrophy ${ }^{26}$ and another with parkinsonism. ${ }^{27}$ These reports indicated that atypical pathogenetic linkage may produce unusual manifestation in KD patients. ${ }^{26}$

Since KD is a systemic and slowly progressive disease, sensory dysfunction develops so insidiously that KD patients usually neglect their sensory problems. It is in part the reason why EPs fail to establish any specific correlation between the pattern of abnormalities and that of clinical deficits. ${ }^{28-31}$
However, electrophysiological studies have proved that KD may produce subclinical EP abnormalities and is characterized with widespread involvement of the nervous system. Abnormal EP findings are not evidence against the diagnosis of KD. If there are potential treatments for KD patients in the future, EPs may be useful in the clinical follow-up.

\section{ACKNOWLEDGEMENT}

We would like to thank Miss WY Shen for the statistical analysis and Mr. Matt Nicodemus for English editing. The study was in part supported by Taipei VGH grant (93-282) and NSC grant (94-2314-B-075-022).

\section{REFERENCES}

1. Harding AE, Thomas PK, Baraitser M, Bradbury PG, MorganHughes JA, Ponsford JR. X-linked recessive bulbospinal neuronopathy: a report of ten cases. J Neurol Neurosurg Psychiatry. 1982;45(11):1012-9.

2. LaSpada AR, Roling DB, Harding AE, Warner CL, Spiegel R, Hausmanowa-Petrusewicz I, et al. Meiotic stability and genotype-phenotype correlation of the trinucleotide repeat in $\mathrm{x}$ linked spinal and bulbar muscular atrophy. Nat Genet. 1992;2(4):301-4.

3. Sperfeld AD, Karitzky J, Brummer D, Schreiber H, Haussler J, Ludolph AC, et al. X-linked bulbospinal neuronopathy: Kennedy disease. Arch Neurol. 2002;59(12):1921-6.

4. Anannontsak A, Massakulpan P, Aksaranugraha S, Phanthumchinda K. Somatosensory evoked potentials in X-linked recessive bulbospinal neuronopathy: a case demonstration. Electromyogra Clin Neurophysiol. 1999;39(7):393-6.

5. Antonini G, Gragnani F, Romaniello A, Pennisi EM, Morino S, Ceschin V, et al. Sensory involvement in spinal-bulbar muscular atrophy (Kennedy's disease). Muscle Nerve. 2000;23(2):252-8.

6. Kachi T, Sobue G, Sobue I. Central motor and sensory conduction in X-linked recessive bulbospinal neuronopathy. J Neurol Neurosurg Psychiatry. 1992;55(5):394-7.

7. Polo A, Teatini F, D'Anna S, Manganotti P, Salviati A, Dallapiccola $\mathrm{B}$, et al. Sensory involvement in X-linked spino-bulbar muscular atrophy (Kennedy's disease): an electro-physiological study. J Neurol. 1996;243(5):388-92.

8. Celesia GG, Brigell MG. Recommended standards for pattern electroretinograms and visual evoked potentials. Electroenceph Clin Neurophysiol Suppl. 1999;52:53-67.

9. Pratt H, Aminoff MR, Nuwer MR, Starr A. Short-latency auditory evoked potentials. Electroenceph Clin Neurophysiol Suppl. 1999;52:69-78.

10. Mauguière F, Allison T, Babiloni C, Buchner H, Eisen AA, Goodin SJ, et al. Somatosensory evoked potentials. Electroenceph Clin Neurophysiol Suppl. 1999;52:79-90.

11. Rothwell JC, Hallett M, Berardelli $\mu$ A, Eisen A, Rossini PM, Paulus W. Magnetic stimulation: motor evoked potentials. Electroenceph Clin Neurophysiol. 1999;:52:97-103.

12. Gelinas D, Callard GV. Immunolocalization of aromatase- and androgen receptor-positive neurons in the goldfish brain. Gen Comp Endocrinol. 1997;106(2):155-68.

13. Adachi H, Katsuno M, Minamiyama M, Waza M, Sang C, Nakagomi $\mathrm{Y}$, et al. Widespread nuclear and cytoplasmic accumulation of mutant androgen receptor in SBMA patients. Brain. 2005;128(Pt 3):659-70.

14. Agapova OA, Kaufman PL, Hernandez MR. Androgen receptor and NFkB expression in human normal and glaucomatous optic nerve head astrocytes in vitro and in experimental glaucoma. Exp Eye Res. 2006;82(6):1053-9.

15. Nunez JL, Huppenbauer CB, McAbee MD, Juraska JM, DonCarlos LL. Androgen receptor expression in the developing male and female rat visual and prefrontal cortex. J Neurobiol. 2003;56(3):293-302. 
16. Cheliout-Heraut F, Barois A, Urtizberea A, Viollet L, EstournetMathiaud B. Evoked potentials in spinal muscular atrophy. J Child Neurol. 2003;18(6):383-90.

17. Simerly RB, Chang C, Muramatsu M, Swanson LW. Distribution of androgen and estrogen receptor mRNA-containing cells in the rat brain: an in situ hybridization study. J Comp Neurol. 1990;294(1):76-95.

18. Buecking A, Pfister R. Sensory ataxia as the initial clinical symptom in X-linked recessive bulbospinal neuronopathy. $\mathrm{J}$ Neurol Neurosurg Psychiatry. 2000;69(2):277.

19. Li M, Sobue G, Doyu M, Mukai E, Hasizume Y, Mitsuma T. Primary sensory neurons in $\mathrm{X}$-linked recessive bulbospinal neuropathy: histopathology and androgen receptor gene expression. Muscle Nerve. 1995;18(3):301-8.

20. Attarian S, Azulay J-Ph, Lardillier D, Verschueren A, Pouget J. Transcranial magnetic stimulation in lower motor neuron disease. Clin Neurophysiol. 2005;116(1):35-42.

21. Sobue G, Hashizume Y, Mukai E, Hirayama M, Mitsuma T, Takahashi A. X-linked recessive bulbospinal neuronopathy: a clinical pathological study. Brain.1989;112(Pt 1):209-32.

22. Nagashima T, Seko K, Hirose K, Mannen T, Yoshimura S, Arima R, et al. Familial bulbo-spinal muscular atrophy associated with testicular atrophy and sensory neuropathy. J Neurol Sci.1988;87(2-3):141-52.

23. Shaw PJ, Thagesen H, Tomkins J, Slade JY, Usher P, Jackson A, et al. Kennedy's disease: unusual molecular pathologic and clinical features. Neurology. 1998;51(1):252-5.
24. Pachatz C, Terracciano C, Desiato MT, Orlacchio A, Mori F, Rocchi $\mathrm{C}$, et al. Upper motor neuron involvement in X-linked recessive bulbospinal muscular atrophy. Clin Neurophysiol. 2007; 118(2):262-8.

25. Karitzky J, Block W, Mellies JK, Traber F, Sperfeld A, Schild HH, et al. Proton magnetic resonance spectroscopy in Kennedy syndrome. Arch Neurol. 1999;56(12):1465-71.

26. Kessler H, Prudlo J, Kraft S, Supprian T. Dementia of frontal lobe type in Kennedy's disease. Amyotroph Lateral Scler Other Motor Neuron Disord. 2005;6(4):250-3.

27. Soragna D, Messa C, Mochi M, Alfonsi E, Manni R, Galimberti $\mathrm{CA}$, et al. Dopaminergic pathways involvement in Kennedy's disease: neurophysiological and $\left[{ }^{123} \mathrm{I}\right] ß-\mathrm{B}$ CIT SPECT findings. J Neurol. 2001;248(8):710-2.

29. Jones SJ. Clinical applications of short-latency somatosensory evoked potentials. Ann N Y Acad Sci. 1982;388:369-87.

30. Halliday AM, McDonald WI, Mushin J. Visual evoked response in diagnosis of multiple sclerosis. Br Med J. 1973;4(5893):661-4.

31. Pierelli F, Garrubba C, Tilia G, Parisi L, Fattapposta F, Pozzessere $\mathrm{G}$, et al. Multimodal evoked potentials in HIV-1-seropositive patients: relationship between the immune impairment and the neurophysiological function. Acta Neurol Scand. 1996; 93(4):266-71. 